\title{
SPACE SECURITY DIPLOMACY IN INTERNATIONAL ORGANIZATIONS: SOME LEGAL ASPECTS ${ }^{2}$
}

\begin{abstract}
Space security is an important area in international diplomacy and is undertaken by international organizations, such as the UN or NATO. This is why diplomatic law is concentrated on space. The outer space domain has become more and more challenging recently. Some challenges are threats, such as cyber or nuclear tests and weapons. In many ways, diplomacy is the only way to negotiate and make progress in ensuring peace and security-which, according to the UN Charter, are key priorities for states. This article shows how international diplomacy is connected to international relations and policies relating to space and how important diplomacy is as a tool to maintain international peace. Law is also one of the tools that help prevent space conflicts and wars among the states. This article outlines some tools of space diplomacy used by states and international organizations, namely, conferences, bilateral dialogues, and other forms of negotiations. It seems that professional diplomatic teams are necessary to achieve diplomatic goals in space. Today, space is connected to politics, trade, and especially the security of states. Thus, the role of space diplomacy is more significant than ever.
\end{abstract}

Keywords: Space diplomacy, security, international treaty, disarmament, diplomacy law.

\section{INTRODUCTION}

Modern diplomacy makes use of not only modern means, but also traditional ones, also (and much more widely) so-called "persuasive measures" in the case of media assistance, dialogue and various forms of negotiation. This requires the involvement of highly qualified professional diplomatic services. Currently, state security and its economic and political interests are closely interlinked, hence the need for effective coordination of defence matters with foreign and trade policy (Łukaszuk, 1999; Miłosz, 2010).

Soon after World War II, the dominance in the Earth and Space of the US and the USSR - two superpowers was asserted. It turned out then that in such a difficult situation the only hope for the achieving balance in space have is diplomacy, called sometimes "space policy?", acting spontaneously on a bilateral and multilateral basis. With the end of the Cold War, more and more states have decided to start operations in Space, and this required, among other things, diplomatic action. At the same period dependence of space applications on the functioning of some systems has raised up significantly.

${ }^{1}$ Małgorzata Polkowska, DSc PhD, Associate Prof., Head of Department of International Law, Institute of Law, War Studies University, 00-910 Warsaw, Al. Gen Chruściela 103; e-mail: m.polkowska@akademia.mil.pl. ORCID: 0000-0002-6633-2222.

2 This publication is financed under the project implemented in the Research Grant Program of the Ministry of National Defense, Republic of Poland. 
Fundamental principles of conduct in space are defined by the UN Charter, which aims at the objective of protecting peace and security in the world. The Charter obliges the member states to solve disputes by means of peace, in case not to endanger international peace, security or justice (Article 2.3), but respects also the right of self-defence.

\section{INTERNATIONAL LAW IN DIPLOMACY}

International legislative acquis in terms of state security in space, it is quite significant. This applies in particular to treaties and bilateral agreements between large spacefaring nations, i.e. the US and Russia. A major diplomatic achievement was the Partial Test-Ban Treaty (PTBT) of $1963^{3}$, which was the first international agreement on the limitation of armed forces in space. This was based on existing legislation - the Outer Space Treaty (OST), which prohibits placing in orbit any weapon-transfer facilities of any kind; nuclear and all weapons of mass destruction. OST prohibits testing and deployment of any weapon on the Moon and on other celestial bodies as well. States-members to the Treaty, in the case of damage caused to different State, shall be obliged to compensate; consultations are envisaged in the cases of potential risks (Article 9). The Treaty emphasized that the action of one state must not interfere with the functioning of another, and ongoing space activities must not damage the space environment (Articles 7 and 9). The 1963 agreement required both of them not to interfere with satellite operations and has become the basis for bilateral provisions the USSR-US agreement of 1971 on limiting the risk of explosion of the Nuclear War ${ }^{4}$, which, inter alia, obliges States to give prior notice on intended launches (Article 4).

The 1972 Liability Convention provides that the launching State is liable for damage caused to third parties by space objects and established a compensatory procedure. The 1975 Registration Convention provided the connection for the relationship between the space object and the launching State. The 1979 Treaty on the Moon prohibits threats and the use of force, and any hostile activity. The treaty prohibits the establishing of military bases, installations, fortifications, arms tests, and conducting military manoeuvres on the Moon (Article 3.4), but allows use of military personnel for scientific or other purposes

Some other international agreements in force concern as well "space security", i.e. the Statute of the ITU provides some rules on the use of radio spectrum frequencies for satellites. Emphasizing the rights of member states to install military equipment (Article 48. 1), also calls on the States Parties to compliance with the no "harmful interference" principles (Articles 45.1 and 38.2). The term 'harmful interference' is defined in the Annex to the statute as an activity that endangers the functioning of navigational or other services, and leads to serious harm, destruction, obstruction or repeated interruption of radio communication services. Nuclear Non-Proliferation Treaty (NPT) $1968^{5}$ of which 189 parties, five are binding, i.e. the powers of Nuclear-Weapon States (NWS) for non-transfers nuclear weapons, other nuclear explosive devices, or technologies for non-nuclear power states calls for action to be taken on the disarmament. NNWS States may not receive, purchase or manufacture nuclear weapons or other nuclear explosive devices (Milik, 2016).

\footnotetext{
${ }^{3}$ PTBT - Treaty Banning Nuclear Weapon Tests in the Atmosphere, in Outer Space and Under Water, Moscow August 5, 1963 [www.state.gov/t/ isn/4797.html (16.11.2017)]. As of October 2011, 125 states ratified the treaty, the depositaries: USA, Great Britain and the USSR.

${ }^{4} \mathrm{http} / / /$ www.nuclearfiles.org/menu/library/treaties/ (09.08.2018).

5 NPT - Treaty on the Non-Proliferation of Nuclear Weapons 1968; www.un.org (16.11.2017).
} 
Article VI of the NPT confers the right to establish zones free of any nuclear weapons $(\mathrm{NWFZ})^{6}$, in which production, acquisition, testing and possession of nuclear weapons is prohibited, with the exception of nuclear energy for peaceful purposes. There are five such zones as laid down in other treaties. NPT is not applicable for production of fissile materials used for nuclear weapons. That prohibition was proposed by the US and negotiated without success at the disarmament conference ${ }^{7}$. The prohibition of proliferation is also enshrined in the Convention on the Physical Protection of Nuclear Material ${ }^{8}$ and International Convention for the Suppression of Acts of Nuclear Terrorism) ${ }^{9}$ is well known as a Convention about the nuclear terrorism. These mechanisms are only partly efficient. Other non-formal agreements (conducted in a diplomatic way) refering inter alia to the states cooperation in nuclear weapon were the Global Threat Reduction Initiative- GTRI and Proliferation Security Initiative (PSI) and unilateral or multilateral agreements about the sanctions. Referring to testing, it's worth mentioning the Treaty from 1963 LBTB (Limited Test Ban Treaty), Threshold Test Ban Treaty TTBT from $1974^{10}$, Peaceful Nuclear Explosions Treaty z $1976^{11}$ and Comprehensive Test Ban Treaty (CTBT) z $1996^{12}$. The latter provides legal framework for prohibiting extensive emissions from nuclear explosions in the whole environment, but it has not entered into force. The CTBT goes further than the 1963 Treaty of the LTBT by providing that no State Party may test nuclear weapons. In 2010182 states signed the CTBT in the year (except India, North Korea, South Korea and Pakistan) and 151 states have ratified it (with the exception of China, Iran, Israel and the US).

With the increasing level of development of ICBM (Intercontinental Ballistic Missile) the US and the USSR perceived the need to engage in limitation of the deployment of nuclear weapons and started diplomatic discussions on this subject - Strategic Arms Limitation Talks - SALT I ${ }^{13}$ caused creation of Anti-Ballistic Missile Treaty $(\mathrm{ABM})^{14}$ and

${ }^{6}$ NWFZ - Nuclear Weapon Free Zone.

7 The 2000 NPT Review Conference established kind of transparency as a permanent element of the NWS nuclear diplomacy. Nuclear governance issues included unilateral declarations and actions: bilateral treaties and agreements; and efforts (mainly limited by the US and Russia) of a multilateral agreement involving NWS and other international arrangements.

8 See: www.iaea.org (16.11.2017). Convention on the Physical Protection of Nuclear Material, Vienna and New York, 3 March 1980 r., IAEA is a depository of the Convention.

9 International Convention for the Suppression of Acts of Nuclear Terrorism, UN 2005; www. treaties.un.org (16.11.2017).

10 The Treaty on the Militation of Underground Nuclear Weapon Tests (TTBT), ratification - US and the USRR, www.state.gov/t/isn/5205.html (16.11.2017).

11 www.states.gov/t/isn/5182.html (16.11.2017), Treaty Between The United States of America and The Union of Soviet Socialist Republics on Underground Nuclear Explosion for peaceful purposes, Moscow, May 1976, Bilateral Agreement US - USRR.

12 www.state.gov/t/avc/c42328.html (16.11.2017), Comprehensive Nuclear Test - Ban Treaty (CTBT) 1996.

13 www.state.gov/t/isn/5191.html (16.11.2017), Strategic Arms Limitation talks (SALT 1); SALT 1 - the first of the strategic arms limitation agreements of 26 May 1972 between the USA and the USSR.

${ }^{14}$ www. state.gov/t/avc/trty/101888.html (16.11.2017), Treaty Between The United States of America and The Union of Soviet Socialist Republics on the limitation of Anti-Ballistic Missile System (ABM Treaty), May 1972; Treaty between the USA and the Soviet Union on the indefinite limitation of the development, testing and deployment of anti-ballistic systems (ABM). 
Interim Agreement on Strategic Offensive Arms ${ }^{15}$. The ABM Treaty banned testing and placement in space of the offshore, land-based and airborne components of the ABM systems (Article V). The Treaty also provided that each party was to not to interfere with the operation of another (through the use of means of verification). Article XII of the Treaty concerns national provisions technical measures such as spy satellites. Signature of the treaty however has not slowed down the pace of development of production and of deployment missile.

At that time, other states, mainly China, were developing the missile technology, which gave rise to concerns about the proliferation of ballistic missiles. The Bush Administration was concerned about the space risks and the 9/11 terrorist attacks in New York have resulted in the US withdrawing from the ABM Treaty within six months. Nevertheless, this first attempt to reduce the risk was an important step towards cooperation and limitation of the weapons supply. The Interim Agreement imposed stopping the number of launches of ICBM and SLBM, which the US and the USSR could do. Abolition of the US-Soviet diplomatic dialogue since the end of the 1970's caused decline in apolitical climate for the creation of the new agreements. This situation resulted, inter alia, from the coup d'état in Iran and the Soviet invasion of Afghanistan. Several agreements were signed,, including $\mathrm{ABM}$, the SALT agreement, which prohibited the interference of the National Technical Means (NTM) and were legally binding on both sides in regards to the restrictions in space (previously existing only in non-binding form) (Rendleman, 2013).

These agreements were preceded by seven years of diplomatic negotiations concluded in Vienna, 1979, by signing of the SALT II Agreement (Strategic Arms Limitation Treaty) ${ }^{16}$. That Treaty put restrictions on equipping the supply of nuclear forces and armaments, and in addition to prohibiting the construction of a new ground launching system and has established the verification rules. In addition, the SALT II Treaty provides inter alia, it freezed launches of strategic missiles on existing level and incorporated the 1987 Level Agreement about nuclear forces (Intermediate Nuclear Forces - INF) ${ }^{17}$.

The US SALT II in 2002 the treaty never entered into force. The proposed confidence building measures (CBMs) in SALT II concerned, among other things prior notification of certain ICBM test launches, arrangements databases for certain systems, consent to noninterference national technical verification measures and obligations of provision of telemetric information. After the US withdrew from the treaty, discussions on an arms reduction agreement have taken place: START I (Strategic Arms Reduction Treaty) ${ }^{18}$ and

${ }^{15}$ See: www.state.gov/t/isn/4795.html (16.11.2017), Interim Agreement between the US and the USRR on Certain Measures with Respect to the Limitation of Strategic Offensive Arms, May 1972, Moscow.

16 www.state.gov/t/isn/5195/htm (16.11.2017), Treaty Between The US and the USRR on the Limitation of Strategic Offensive Arms (SALT II) June 1979, Strategic Arms Limitation Treaty (II) SALT II - the second round of negotiations on the limitation of the strategic arms between the US and the USSR culminating in the signing of a treaty setting quantitative and qualitative limits on strategic arms systems.

17 www.state.gov/t/avc/trty/102360.html (16.11.2017), Treaty Between The US and the USRR on the elimination of their intermediate - Range and Shorter-range Missiles.

18 www.nti.org (16.11.2017); Treaty Between The US and the USRR on Strategic Offensive Reductions (START I) - START I - the first of the strategic arms reduction agreements in the START series, concluded between the USA and the USSR in July 1991, expired in December 2009. 
CTBT (Comprehensive Test Ban Treaty). Finally, START I was signed by the USSR and the US in 1991. It concerned the introduction of transparency and building measures of mutual trust. The TCBM has strengthened the originating provisions of the 1988 Ballistic Missile Launch Notification Agreement ${ }^{19}$ by providing rules for prior notification of ballistic missiles, used as amplifiers for launching objects into the upper atmosphere or space. Moreover, START I has determined the limits for launching equipment and the announcement of the first strategic nuclear weapons reduction in the US and the USSR (agreed on the liquidation of 6 thousand warheads within 10 years). INF Treaty of 1987, obliged the US and the USSR to eliminate and permanently liquidate their operations all (medium and short range) nuclear missiles and missiles, with a range of $500-5,500 \mathrm{~km}$, as well as launching equipment for controlled projectiles. Whereas the Treaty was applicable to all missiles on Earth, independently on their configuration and supply, this was a good step in the area of arms control, following arms control treaties such as START I and the Treaty on Conventional Forces in Europe (CFE). INF introduces the principle of compatible destruction of the whole category of nuclear weapons and the principle of verification with data exchange mechanisms. The verification protocol confirmed the reductions in weapons through the use of national technical measures (e.g. satellite observation) and inspections in situ. In Article XII of the INF, the parties agreed not to bury the other party's NTMs and not hide the weapons, which would endanger the verification process. Inspections are divided into few groups: basic inspections (with the purpose to verify the exchange of data on equipment that is about to be restricted and listed under the Treaty), closed (examining INF termination), elimination (confirming the destruction of projectiles, launching devices and associated damage equipment), rapid surprise inspections (maximum permitted $20 \mathrm{such}$ inspections per year in the places designated by the Treaty during the first 3 years of implementation and after 15 inspections made annually in the next 5 years), follow-up inspections in places where missiles have been produced in the past (only in two locations in Russia and USA).

The INF Treaty has therefore become the first agreement, aimed at reducing nuclear arms, with a control mechanism. However, neither INF nor START I obliged the State-Parties to destroy nuclear warheads. The START I agreement pressured the USSR to destroy more than 3 thousands ballistic missiles, 45 atomic ships and more than sixty five strategic bombers. The US has destroyed more than 3 thousands missiles and a significant number of firing devices and bombers. Another 1989 agreement between the two space powers concerned the prevention of unsafe military activities (Prevention of Dangerous Military Activities Agreement - PDMA) (Campbell, 1991-2). The aim of the agreement was to prevent hazardous activities from occurring in peacetime. It has therefore become important to establish the following provisions in order to avoid accidents and military provocations in space. Part of this task was to avoid ambiguities during peaceful exercises and normal operations. The contract was relevant to subsequent bilateral agreements between the two countries.

\footnotetext{
${ }^{19}$ www. state.gov/t/isn/4714.html (16.11.2017), Agreement Between The US and the USRR on Notifications of launches of Intercontinental Ballistic Missiles and Submarine-Launched Ballistic Missiles (Ballistic Missile Launch Notification Agreement), May 1988.
} 
In 2002, Presidents Bush and Putin in Moscow signed the Treaty on the reduction of strategic and offensive forces (Treaty on Strategic Offensive Reductions) ${ }^{20}$. This Treaty complemented START I of 1991 and called for a further reduction of the head and delivery systems by two third. Both sides have identified their strategic forces (according to limited number of warheads) and established the bilateral implementation committee with intention to meet twice a year, to discuss matters that could appear in connection with the Treaty application. A new Strategic Arms Limitation Agreement was signed by Presidents Barack Obama and Dmitry Medvedev in 2010²1. It replaces the 1991 START I Agreement, the Treaty on the Functioning of the European Union from Moscow in 2002 with strategic restrictions on the offensive (SORT) and the 2009 non-binding contract. The new agreement limited number of nuclear warheads up to 1550 and number of launching units. The contract is also accompanied by an inspection programme. Agreement still needs to be ratified by both states. It shall apply only to strategic nuclear weapons (rather than "tactical" nuclear weapons and strategic warheads). Treaty protection of national technical measures NTM (mainly spy satellites) on the monitoring of Treaty obligations, was also enshrined in the 1974 Treaty (Threshold Test Ban Treaty), from 1976 (Nuclear Explosions Treaty), from 1987 (Intermediate Range Nuclear Forces Treaty) and the CFE from $1992^{22}$. Some scientists do not agree that protection and legitimacy of satellites was properly restricted by those treaties. According to them international law remained ambiguous in this respect, so as in the case of ASAT weapons.

The START III project concerned nuclear disarmament of the US and Russia. Negotiations were unsuccessful and therefore no contract was signed. Only the new START system is still in force today (concerning missiles with nuclear weapons) - signed 8 April 2010. It entered into force on 5 February 2011 following ratification by the two states and is due to expire definitively on 5 February 2021. Control of the arms and weapons race of the Space through bilateral agreements was effective in times of the Cold War, whenever the USSR and the US were technologically capable of developing strategic weapons. The end of the Cold War changed this situation. The result is a further need to take appropriate measures in view of the danger of arming the space and increasing involvement in it other States in space activities. Even during the Cold War, the UN became a platform on which diplomats from the US and the USSR were involved in negotiations on space exploitation issues. This is where the important decisions have been taken (mostly in the form of

${ }^{20}$ www.state.gov./t/avc/trty/127129.html (16.11.2017), Treaty Between the US and the Russian Federation on Strategic Offensive Reductions (The Moscow Treaty), May 2002 - The agreement, signed at the Bush-Putin Summit in May 2002, announced a reduction in the number of nuclear warheads to 1700-2200 for both sides by the end of December 2012 and confirmed the validity of the START I agreement.

${ }^{21}$ www.state.gov/t/avc/newstart/html (16.11.2017), New Strategic Arms Reduction Treaty (NEW START, CHB-III) - the bilateral treaty between the US and Russian Federation on measures to further reduce and limit strategic arms, signed on 8 April 2010. It entered into force on 5 February 2011, once the parties had ratified this agreement.

${ }^{22}$ CFE - Treaty on Conventional Armed Forces in Europe - Treaty on Conventional Armed Forces in Europe, Framework Agreement concluded in Paris on 19 November 1990 between NATO countries and the Warsaw Pact, formally concluding the second round of the Vienna disarmament negotiations of the CSCE (Conference for Security and Cooperation in Europe); entered into force on 9 November 1992. Poland notified the Netherlands (a depository) of its accession to the Treaty on 26 November 1991. 
a resolution), with the intent to facilitate the conclusion of agreements and contracts of international organisations. UN Security Council Resolution 1721 (XVI) from 196123 ordered the use of international law, in particular the UN Charter to the Space.

\section{COLD WAR ASPECTS IN DIPLOMACY}

When the US-Soviet talks on the following were suspended in 1980 in addition, the USSR has requested the UN to add the following to the list of persons to be included in the list of States Parties to the Convention agenda for an international arms embargo agreement. Subsequently, on the initiative of a group of Western countries, the Committee was set up the European Disarmament Authority (now called the Disarmament Conference) with developing methods for avoiding agreement. This is because the European Union is a global player in the area of arms in space and prohibits the use of anti-satellite systems. The Assembly has expressed in a very clear manner the view that the military use of the Space is against the OST. In its 1981 Resolution, the United Nations called on States to continue the peaceful use of space and the prevention of an arms race and recognized the need to develop a space law. Still in 1981 a group of diplomats from Western countries, headed by Italy, formed a coalition with the USSR at the UN aimed to move a resolution on arms control in space ("Prevention of an Arms Race in Outer Space" - PAROS) ${ }^{24}$ in motion".

The resolution called on the Disarmament Committee to negotiate the agreement referring to the prevention an arms race in space and considering that military use of force in space is against the OST $^{26}$. In 1983, the USSR proposed to dismantle its ASAT system, but President Regan's administration did not believe in Moscow's good intentions. Meanwhile, in 1985 Soviet leader Mikhail Gorbachev suggested creation of the International Committee on Space to ensure that its peaceful use and to help create a new treaty against arms. After all, the UN has transferred these proposals to The Conference on Disarmament, where the PAROS ad hoc committee held discussions on the prevention of the arms race in outer space (1985-1994) and on mechanisms for strengthening cooperation on space security. The Regan administration took part in these talks and the bilateral negotiations, but treated them as a Soviet request blocking of the SDI programme and other US activities. However, some progress has been made in work of the disarmament conferences on a draft treaty on the prevention of an arms race in space. The FMCT Treaty was almost complete, but in 1995 China has stated that it will support it when PAROS at the same time would be considered. U.S. opposition to Chinese proposal caused, amongst others, a blockage of negotiations.

Although The UN approves PAROS resolutions every year, in practice only few of them are effective, as there is no consensus among countries on the agenda and placement. This is where the discussion about space security, as required by the resolution, takes place.

\footnotetext{
${ }^{23}$ Resolution adopted by the General Assembly 1961 - 1721(XVI) International Cooperation in the peaceful uses of outer space.

24 www.un.org (16.11.2017).

25 www.un.org (16.11.2017).

${ }^{26}$ In 1958, The US President Eisenhower first called for the principles of using the Space for peaceful purposes to be respected. Later the same year, the UN General Assembly established the Committee on the Peaceful Uses of Outer Space (UNCOPUOS), which stressed the importance of outer space as a Common Heritage of Mankind - CHM ("The Common Heritage of Mankind"). In 1959 , the Assembly decided to change the ad hoc committee as a permanent body.
} 
Thanks to diplomatic negotiations, it was possible to adopt the 1992 UN resolution 47/68: 'The Principles Relevant to the Use of Nuclear Power Sources in Outer Space', which established the criteria for the safe use of radioactive material in outer space and the reduction of nuclear satellite disasters ${ }^{27}$.

Resolution 51/122 „Declaration on International Cooperation in the Exploration and Use of Outer Space for the Benefit and in the Interest of All States, taking into Particular Account the Needs of Developing States" from 1996 called the states operating in the space to cooperate (Article 3) and recalls that States Parties have the freedom to present all aspects of their activities in international collaboration of exploration and the use of outer space (Article 2); international scope of cooperation is left to the decision of the member states ${ }^{28}$. As already mentioned, discussions in the Disarmament Committee in the UN, on the prevention of an arms race in space (PAROS) were interrupted in 1995, when China insisted, to connect PAROS to the Fissile Material Cut-off Treaty (FMCT) concerning fissile materials. Such a proposal could not to be accepted by the US.

\section{FAILURES AND SUCCESSES OF SPACE DIPLOMACY IN THE $21^{\text {ST }}$ CENTURY}

Since the mid-1990's, diplomatic negotiations on The Space Arms Treaty have been suspended. It was only UN Resolution 61/75 of 2006, proposed by Russia, and invited the States Parties to give information about its initiatives towards confidence-building measures to strengthen PAROS resolution 62/43 ${ }^{29}$. The UN resolution has referred to the report of the UN Secretary-General and to specific issues such as proposals by member states on confidence-building issues ${ }^{30}$. Moscow and Beijing wanted to reopen negotiations in the framework of the $\mathrm{CD}$ conference on arms control. Additionally, Moscow tried also to reduce the US missile defence by insisting on the maintenance of the ABM Treaty, allowing for the some systems operation, compliant with demarcation agreements, for the time of preparing the national missile defence. Such restrictions have met with strong opposition from the US. Only in 2009 thanks to the compromise between China and the US - the FMCT and other issues referring to the space security could be put on the agenda of CD.

A few months later, that consensus was blocked by Pakistani diplomats and the topic was withdrawn from the agenda again. In the American strategy developed in 2011, a major role was played by Space diplomacy was the focus of attention. Although President Obama pointed out the need for confidence-building measures (TCBMs), he namely considered that they have limited practical relevance. China, in turn considered that, in order to be binding, such measures should be included in an international treaty. The Chinese ASAT test in 2007 discovered the "grey area" in the global market for space legislation, where the OST Treaty was not respected. It required prior notification to other states in the case of activities which could have caused harmful interference for other state's space programmes.

In addition, after that test thousands of dangerous debris have been created, and none necessary consultation was conducted on this topic. Already in 2005, Russia, together with some other countries, proposed the adoption of a following UN resolution - "Transparency and Confidence-Building Measures in Outer Space". This proposal was successful in

27 A/RES/47/68; www.un.org 16.11.2017).

28 A/RES/51/122; www.un.org (16.11.2017).

${ }^{29}$ A/RES/61/75; Transparency and Confidence - building measures in outer space activities, 2006.

${ }^{30}$ A/RES/62/43; Transparency and Confidence - building measures in outer space activities, 2008. 
international society (without US). 2010 versions of the project suggested that a representative group should be convened government experts analysing the subject of space transparency and preparing recommendations for the UN. This time American diplomats participated in the group's meetings in 2012 and 2013 and took part in the editing of the CGE report, published in 2013. This document indicates, inter alia, the need to provide a disaster warning, reduction of residual amounts space, monitoring and development of commercial activities in space ${ }^{31}$.Weakness of the supervisory mechanisms in the current international space law and security gaps in security matters have led to a series of questions about their adaptability to reality.

Conference on Disarmament in Geneva - CD (UN Conference on Disarmament), which is responsible for the negotiations on international arms control has not acted since the 1990's on account of difficulties in reaching agreement between the States. There is certainly a lack of confidence in the creation of treaties binding to each of the superpowers: US, Russia and China. The need for international cooperation began to be discussed in the following terms: when LEO and GEO orbits are full, when space is full of space debris and the end of the spectrum radio frequencies for satellites has been observed. The risk of collision increases, but it is not reasonable to assume that nothing can be done to avoid them. The efforts of the international community, such as creation UN Space Debris Mitigation Guidelines and its initiative of creating the International Code of Conduct for Space of Conduct for Outer Space Activities are a good example of this and are targeted at to create more precise procedures for maintaining peace and stability. To this day, Space has remained the only environment (with the exception of the Antarctic), which have not witnessed any imminent international conflict. However, new participants in the race to Space, like China, among others, cause the need of creating more programmes and policies. On the other side the chance of a conflict or a situation in which accidents (of military object) may happen is rising. In addition, commercial use of space and increasingly advanced technology, are conducive to an increased number of conflicts, which, for the time being, have been resolved by ,space diplomacy”.

As already mentioned, treaties and other agreements concluded by states did not prohibit military activities in the 1960's and 1970's in space. Still in the international Treaties uncertainties exist in relation to the space activities. There is no treaty that prohibits nonnuclear testing weapons in space (including kinetic missiles, lasers, and electronic jamming devices), there is not restrictions against placing such weapons on the orbit. There is only voluntary legislation on the prevention of pollution by states Space with space debris. The only existing standard here is an obligation to give prior notification to such an event. A big problem is the destructive effect in the most frequently used areas, space regions (LEO and GEO), risks due to unhindered proximity to military operations and testing of new ones weapons systems (laser, capture and microwave systems). States develop different types of space weapons mainly due to the fear against the activities of others. In this context it seems necessary to extend the reach of the new security mechanisms.

If leaders declare, that by their actions they will introduce stability and security, they could lead the international community by example. This could give rise to the creation of

\footnotetext{
${ }^{31}$ Study Series No. 34, Transparency and Confidence - Building in Outer Space Activities, UN,
} Office of Disarmament Affairs, New York 2013. 
international standards, which countries would accept, implement and apply ${ }^{32}$. The last farthest option is the possibility to conclude new international agreements involving many countries. These include Code of Conduct, Conventions (e.g. 2007 UN Space Debris) and with the formal treaties. Depending on the nature of the agreements, levels of national requirements and surveillance mechanisms, negotiations on the conclusion of these agreements can be more effective, or less complicated, but always worth every price. Thanks to them trust, stability and effectiveness are among the values of active defence of peace in space. Therefore, space diplomacy should focus on the creation of a new Security Treaty in space and the establishment of a new organisation monitoring Space and warning of potential collisions (Hart, 2007).

The subject of space security has been discussed on various levels. International debates on strengthening space security ranged from expert proposals to the creation of space organisations with a wider scope and more specific new developments of the space treaties, up to and including non-binding codes of conduct, and finally the discussions at the UN, including UNCOPUOS. However, it is difficult to achieve the consensus on an area where dual-use and new technologies exist is a mutual trust partner.

International space collaboration in space matters is directly related to the subject of arms control, disarmament and proliferation. This link exists because of the sophisticated high level of this cooperation, which demand from countries to have access to, and to develop and share the space equipment and technologies. Environment safety is very important for states to assess whether it is in their national interest to cooperate with others (Meyer, 2016).

Lack of international control will raise States' concerns about their security. The lack of space arms control and verification measures results in an increase in the likelihood that other developed, large countries could be considered as strategic military competitors.

Countries are reluctant to be active in cooperation within such organisations. In addition, the inclusion of countries with less sophisticated technology and knowledge raises concerns for leaders actors about possible unauthorised re-transfers and originating technology. With no comprehensive international technology control regime space, joint development, sharing and transfer of space know-how constitutes a individual safety risk. There are four issues referring to arms control, disarmament and proliferation: Anti-Satellite (ASAT) weapons, missile defence systems, proliferation of ballistic missiles and launching devices, and unauthorized technology transfer for ballistic missile development, space weapons and other military space applications.

In case of implementation of a clear international system controls for civil and commercial technologies and equipment in space, a gap related to arms control should be closed. Unfortunately, at present the States are reluctant to engage in international projects, which will expose them to an unauthorised transfer of technology. Resolutions bridging gaps in arms control, disarmament and proliferation can alleviate these concerns. Regarding ASAT's (anti-satellite weapons), there are no international agreements prohibiting or controlling the development, placement or the use of such weapons. As the Chinese test in 2007 showed, this is a high danger to the outer space. With regard to space weapons (with no weapons of mass destruction) a global agreement prohibiting or supervising the

${ }^{32}$ The main target of the OST is, to define the basic instructions for the states how to use the space in peaceful manner. These rules cover many different aspects of exploration of space (Articles I and II). 
development, placement, or the use of such weapons is needed. There is no international system of control either. There is also no international system for regulating applications. Moreover, there is a lack of international system for the verification of civil and commercial programmes which shall not be used to complement military programmes for ballistic missiles. On the other hand, there is no international programme encouraging the participation of States in civil programmes and commercial launches. This lack of transparency results in crisis of confidence and in uncertainty about possible involvement in space cooperation projects. There is also no global agency to provide peace usage of outer space technologies and abandonment of using space technologies for military purposes. Although there are organisations controlling the use of technologies such as nuclear or and chemical, but they do not have references to space technologies.

There are no global regimes with independent verification mechanisms to determine whether launchers, devices or space technologies are not used for military purposes. However, there are several global restrictions on the military use of space. As long as their targets are not aggressive and do not violate OST regulations (prohibiting the military use of bodies) States may use space for the military purposes. The main concern about the militarisation of Space is related to the increasing numbers of military system applications to support ground-based operations and big disproportions in those applications of modern weapons systems. Military satellites are becoming increasingly important in the current warfare. Currently, States may, under international law place weapons in space. It is true that there are legal limitations with regard to the type of weapon that can be deployed; however, in some cases the scope of these restrictions is confusing. This could lead to a discussion that could endanger international safety and security. This discussion could occur if states would be interested in space militarization by using the loopholes in the existing space legislation. The legal regime needs transparency and does not provide for a specific mechanism for resolving disputes.

The requirements of the 1975 Registration Convention provide little transparency; states can therefore register arms with impunity in space as civilian objects. The OST provides only how to use international law and the UN Charter, and in addition Article IX calls for global consultation. However, it is not clear, whether the deployment of weapons also requires this obligation, and to what extent these consultations should be carried out. For decades, the international community has been working on a ban or to limit the type of weapons by defining acceptable conditions, its use and location. Many of these measures were recognised as arms control. Such control may not, however, be exercised. It is identified, for example, with peace treaties or border agreements, which sometimes only concern arms. Arms control is not a humanitarian law but rather a branch of war law. Humanitarian law does not limit the number, type, of or the location of the weapon only specifies which weapon can be used during the war. It is easier for the State to renounce the right to acquire new assets military technology, than to dispose of weapons already in its possession (Onley, 2013).

Reaching precise global agreement on reduction is an extremely difficult process. It is easier to obtain consent on one issue than another or conclude a bilateral rather than a multilateral agreement. However, the multilateral agreement has more advantages. Similarly, the Treaty has an advantage over soft law. It is also important that the treaties contain verification regimes that prevent breaches; and the practical time-limits for withdrawing from contracts. Contracts aiming to control arms are a major challenge in international security. The history of arms control points to a number of errors which must 
now be avoided. It is important to build a space law regime that will serve to safeguard the security interests of the community of international and individual members of spacefaring nations. In some cases, the model of existing arms control approaches can be applied to space. Faced with stagnating disarmament of diplomatic conferences and the opposition of the US to the new space treaties, the countries of the European Union seek a different path for improving the situation of international security in space. One of the sources, from which the EU has benefited, was the initiative of an American non-governmental organisation the Stimson Centre, where the proposal of a code of conduct in space was born $^{33}$.

In 2010, the EU amended the draft and has prepared its own version of the Code. The new Code proposed that states would voluntarily become parties to it, promoting safe use of space and security principles (consensus norms) - like members of a club agree to behave in accordance with certain rules. Those principles of the Code shall include the following provisions: non-interference with the operations of other space objects, actions to minimise the possibility of satellite collisions, and taking part in creation of a common electronic database and consultation. Some principles of the Code repeats and strengthens certain elements of the OST and other legislation, in a way collecting them into a single document with an emphasis on all measures of protection of space against possible conflict (Chanock, 2013.

In relation to other initiatives, the efforts made at UNCOPUOS in Vienna should be mentioned. Over the last two decades, its mandate was based on international rules of the cooperation of State Parties in peaceful activities in space environment and disarmament conferences that deal with arms control and security issues. Their success in speeding up the agreement on the fight against space debris was due, among other things, to the introduction of annual meetings of the Space Council diplomats from various countries. More recently, this forum has considered space applications topics, space warnings against natural threats and monitoring of orbital remains. It is necessary to conclude that UNCOPUOS is performing much better and faster than others. Some observers suggest that the discussion should be postponed of Space security from the Disarmament Conferences (CDs) to UNCOPUOS, but states do not want to deprive conferences of their significance (for reasons of merit in setting up the arms control forum).

Academic discussions sometimes return to the idea of new international space organisation. Another idea (Voltaire) concerns vocation of the Organisation for Common Security in Outer Space (OCSO), similar to the International Atomic Energy Agency. The Treaty would limit offensive activities in space and would ban defensive and destructive activities, as well as the deployment of weapons. The Treaty would require destruction of existing ASAT weapons. With regard to dual-use weapons, Voltaire proposes an international system to verify its deployment. The new organisation would oversee space activities and ensure an early warning system for launched missiles. In addition, it would assist in the development and implementation of regulations on space activities. By the way, it would absorb some UN bodies, such as UNCOPUOS. However, this idea would require the consent of official governments, mainly those of large countries (Polkowska, 2019).

As already mentioned, another diplomatic success was the progress in addressing the issue of space debris. After the US test with ASAT in 1985, and the criticism that this triggered from parties of the international community, US Department of Defence began

33 www.stimson.org (16.11.2017). 
bilateral talks with his allies and the USSR on the issue. Cooperation between the USA, Japan, Europe (ESA) and Russia lead to establishing the IADC (Inter-Agency Space Debris Coordination Committee) in 1993. This has led to the development of the project Guidelines for Best Practices in Debris Mitigation, including among other things, the ban on the use of hazardous devices. IADC has called on States to refrain from using long-lived materials in satellites (which are difficult to recycle) and for their transfer from orbit GEO into higher orbits to avoid collisions. Thanks to the cooperation of IADC and UNCOPUOS (to develop voluntary good practices) the Space Debris Mitigation Guidelines have been developed and approved unanimously by the UN Assembly in December 2007. This initiative has triggered further plans to reduce congestion objects in low orbits, which was necessary to limit collision and ensuring the functioning of the private sector (by ensuring stability and control mechanisms) in shared environment.

The principles of the IADC have been replicated in their policies by, inter alia the US. In 2006, the Bush administration developed a national programme for Space policy (proclaiming freedom of action in space). This programme was changed by President Obama in 2010; it was argued, that full independence of space activities is not possible in the $21^{\text {st }}$ century. If all states had invoked freedom of action without restrictions, the space could be destroyed by orbital remains and other hazards. It is in the interest of each State to create rules limiting the harmful effects on the space. This means that all states must give up part of their freedom in order to protect a space that they can use without fear (Fuller, 2017).

\section{CHALLENGES TO THE SPACE DIPLOMACY FOR FUTURE}

Space diplomacy will play a very important role in future as well. During COPUOS sessions in 2017 a need to strengthen existing mechanisms and forging new mechanisms in global collaboration in space activities was presented as 2030 Agenda for Sustainable Development for Space.

Space diplomacy, built on existing norms and negotiated treaties, refers to cooperation among nations on the basis of equal engagement and mutual respect. Building the constructive partnerships. The continuous growth and differentiation of space activities can be attributed to combined and sustained efforts at the national, regional and global levels to foster international cooperation in the peaceful uses of outer space, in particular within the COPUOS, as the main global platform. The next objective of the space diplomacy is to strengthen its pillar by building upon existing partnerships and creating new partnerships in space activities or by addressing "space exploration and innovation" as an agenda item of the COPUOS. Space diplomacy should enhance the safety, security and sustainability of outer space activities. The most important is here to protect of space assets, space systems and critical infrastructures. Diplomacy should build upon the existing network of the Office for Outer Space Affairs and strengthen its global and regional presence. There is a need to create as new item on space exploration and innovation to be added to the agenda of COPUOS to enable spacefaring and non-spacefaring nations to continue discussing important issues regarding humanity's horizons in space and to facilitate the possibility of exploration and innovation objectives.

Moreover it was recommended that a new item on space and global health be included in the agenda of the Scientific and Technical Subcommittee under a multi-year work plan, also it is recommended to establish a new working group dedicated to the topic. It was 
recommended also to establish an international coordination group for space weather. It was also recommended for the safety, security and sustainability of space activities to be enhanced, by protecting the space assets, space systems and critical space infrastructure. The annual convening is recommended by the high-level forum: Space as a Driver for Socio-economic Sustainable Development. It has also been recommended to strengthen existing partnerships of the Office for Outer Space Affairs and creating new ones. The strengthening is recommended for the global and regional presence of the UNOOSA as the gateway to space in the United Nations system. The Office could build on the existing network of regional centres for space science and technology education, and explore how the highest diplomatic levels in New York and Geneva can be engaged in its work in space diplomacy, global governance of space activities and the universality of the space treaties with a possibility of creating further synergies in the space-related work within the UN system and enhancing the delivery of UN space-related services to meet the needs of Member States ${ }^{34}$.

\section{NATO IN SPACE SECURITY}

NATO is more involved in space which is more and more challenging. Some challenges are threats such as cyber or nuclear tests and weapons. Until now, NATO air and land forces have been based on modern computers. As dependence on computers increases, so does the need for cybersecurity. Resilience means that key elements of the armed forces should function even in conditions of interference. However, in the case of a cyber-attack and the resulting computer failure, standard planning procedures and processes for military operations deteriorate. Cyber-attacks against critical infrastructure can reach very high levels of destruction and are difficult to identify, and often the perpetrators - individuals or states - cannot be identified. In this situation, NATO, under the influence of the United States, decided to use space equipment and weapons to defend its members. This article attempts to locate the above arguments in the update of the more involvement of NATO into space operations and space security.

Space seems to be a domain of warfare as others (like land, air or maritime), that is the reason why NATO seems its growing interest in engaging forces into space. The aim of the article is to consider if NATO should be more involved into space. The methodology used consists of analysis of the existing rules and needs in this domain. In the view of the above, it seems reasonable to seek answers to some research questions referring to the necessity and rationale of the involvement of NATO states in the space domain. There are also some question referring to NATO activities and declarations referring to multi domains operations, such as in space. It is also crucial to think about the international cooperation and policy of the largest Western European countries, which have decided to increase the financial outlay on their armies and space equipment. The distribution of weapons in space by the West gives their opponents an important political and propaganda argument and may cause a dangerous escalation of nuclear weapons in Russia and China and the possibility of their use on Earth or in space. Those considerations will form the content of the article by comparing and discussions some legislation and documentations coming from last NATO meetings and conferences in the above subject. There are a lot of publications referring to

\footnotetext{
${ }^{34}$ A/AC.105/1166, 13 December 2017, General Assembly, V.17-08851 p. 22; COPUOS, The "Space2030" agenda and the global governance of outer space activities, Note by the Secretariat. Space diplomacy. Strategic objective 4.
} 
NATO itself. Among many there is "NATO at 70's -A Historiographical Approach" by L. Risso; NATO's Security Discourse after the Cold War : Representing the West by A. Behnke; "NATO and the Enlargement Debate : Enhancing Euro-Atlantic Security or Inciting Confrontation by T. German) or its recent cybersecurity activities, such as "Politics, Governance and Conflict in Cyberspace" by D, Van Puyvelde and A. F. Brantly; "Operationalizing Cyberspace as a Military Domain: Lessons for NATO" by Rand Corporation (US), "Digital war- a critical introduction" by W. Merrin, or "Understanding Cyber Warfare: Politics, Policy and Strategy" by Ch. Whyte.

Not many of the publications refer to space itself. Some of them are the publications of the Joint Air Power Competence Centre (JAPCC), a member of the NATO management in Brussels, and on the notes of the author, who participated in NATO conferences in Turin and Essen in 2019 (Air \& Space Power in NATO, Future Vector, Part I, July 2014, Part II October 2014; Command and Control of a Multinational Space Surveillance and Tracking Network, June 2019; The Journal of the JAPCC, Edition 28, Spring/Summer 2019; and the publishing house NATO Command \& Control Centre of Excellence, Study, Part One 2019 Cyber- resilience towards cyber-reliance, White Paper, ebrc, Luxemburg [2019]; Joint Air \&Space Power. Readhead. Conference 2019, Shaping NATO for Multi-Domain Operations of the Future, 8-10 October 2019 (Essen Conference); publication and, own notes from the conference (SCI-318 Specialists' Meeting (RSM) on 'The Space Domain and NATO Operations: A Critical S\&T Review' Army Education \& Training Command, and School of Applied Military Studies, Turin, Italy, 25-27 June 2019; conference minutes and author's notes as well as a number of other studies, including on space weapons (Chanock, 2013; Aliberti and Lisitsyna, 2019) and the security system in cyberspace as well as articles posted on the Internet.

\section{THE LONDON DECLARATION}

During last meeting of NATO heads of States in London (3-4 December 2019), the 29 NATO on Wednesday the $4^{\text {th }}$ of December 2019 jointly declared space a "domain of operations" during a meeting in London in NATO's 70 $70^{\text {th }}$ anniversary. The decisions taken there were of high significant importance. Space was declared as the fifth operational domain for NATO, together with land, air, sea, and cyber. So called "London Declaration" has been issues by the states and governments participating in this meeting celebrating seventy years of the creation of the Alliance. NATO as has been declared must be a guarantee of the security of all allies states ant their citizens. The idea of NATO is to work together in case to secure peace and to prevent conflicts (North Atlantic Treaty from the $4^{\text {th }}$ of April 1949). According to Art. 5 of the Treaty an armed attack against one or more of them in Europe or North America shall be considered an attack against them all. At the same time states consequently agree that, if such an armed attack occurs, each of them, in exercise of the right of individual or collective self-defence recognised by Article 51 of the Charter of the United Nations. NATO states are ready to respond to cyber-attacks, hybrid tactics, nuclear, conventional, and missile defense capabilities worldwide. States must preserve and strengthen of arms control, disarmament, and non-proliferation. Moreover, NATO states are obliged to implement and use of the international Treaty on the NonProliferation of Nuclear Weapons. 


\section{CONCLUSION}

It seems that today diplomacy has an important role to play in space security. Recently, more international organizations, not only strictly in space civil domain as UNCOPUOS or UNOOSA, but also in military domains (such as NATO) are involved in space. Space security is connected to the politics and international relations having the over cross-border nature. That is the reason why space diplomacy became so crucial these days. There are many diplomatic tools necessary to obtain the diplomatic targets. Some of them are traditional, such as negotiations of international agreements and conventions (making hard law), some of them have different nature (soft law). One is sure not only professional diplomats are necessary here, but also experts working in international organizations and those who are representing states. Security law is one of the diplomatic tools which help states to prevent conflicts on Earth. Even though negotiated contracts in space security are necessary to cooperate for states in space, some other forms of law (soft) has even more significant meaning and role to play. Hopefully in the future international space community can form kind of Code of Conduct in space as Common Heritage of Mankind as it was declared in the Outer Space Treaty in 1967. Maintaining the peace in space is one of the priorities for worldwide security. That is why diplomacy in space security needs to be as professional as ever today.

\section{REFERENCES}

A/RES/47/68; www.un.org (16.11.2017).

A/RES/51/122; www.un.org (16.11.2017).

A/AC.105/1166, 13 December 2017, General Assembly, V.17-08851.

http://www.nuclearfiles.org/menu/library/treaties/ (Access: 09.08.2018).

A/RES/61/75; Transparency and Confidence - building measures in outer space activities, 2006. A/RES/62/43; Transparency and Confidence - building measures in outer space activities, 2008.

Campbell, K. M. (1991-1992). The U.S.-Soviet Agreement on the Prevention of Dangerous Military Activities. „Security Studies” No 1, Vol. 1. DOI: 10.1080/09636419109347459.

Chanock A. (2013). The problems and potential solutions related to the emergence of Space Weapons in the $21^{\text {st }}$ Century. JALC No. 4, Vol. 78.

Fuller, T. (2017). Measuring space debris risk. „Room, The Space Journal” No. 3(13).

Hart, B. L. (2007). Anti-satellite weapons, threats, laws and the uncertain future of Space. Institute of Air and Space Law, McGill University. Montreal: McGill library.

Łukaszuk, L., ed. (1999). Dyplomacja wspótczesna a problemy prawa $i$ bezpieczeństwa międzynarodowego. Warszawa.

Meyer, P. (2016). Prospects for progress on space security diplomacy. „Room, The Space Journal” No. 4(10)

Milik, P. (2016). Rules for the transfer of weapons and military technology in the light of contemporary international law. „Security and Defence Quarterly” No. 13(4). DOI: $10.35467 / \mathrm{sdq} / 103233$.

Miłosz, S. (2010). Dyplomacja wspótczesna i protokót dyplomatyczny. Teoria i praktyka. Warszawa.

Onley, R. D. (2013), Death from above? The weaponization of space and the threat to International Humanitarian Law, JALC No. 4, Vol. 78. 
Polkowska, M. (2019). Space Situational Awareness (SSA) for Providing Safety and Security in Outer Space: Implementation Challenges for Europe 2019. "Space Policy Journal", available online 20 December 2019. DOI: 10.1016/j.spacepol.2019.101347.

Rendleman, J. D. (2013). Brave New World of Hosted payloads, JSL No. 1, Vol. 39.

Study Series No. 34, Transparency and Confidence - Building in Outer Space Activities, UN, Office of Disarmament Affairs, New York 2013.

New Strategic Arms Reduction Treaty (NEW START, CHB-III).

www. state.gov/t/avc/trty/101888.html (16.11.2017).

www.iaea.org (16.11.2017).

www.nti.org (16.11.2017).

www.state.gov./t/avc/trty/127129.html (16.11.2017).

www.state.gov/t/ isn/4797.html (16.11.2017).

www.state.gov/t/avc/c42328.html (16.11.2017).

www.state.gov/t/avc/newstart/html (16.11.2017).

www.state.gov/t/avc/trty/102360.html (16.11.2017).

www.state.gov/t/isn/4714.html (16.11.2017).

www.state.gov/t/isn/4795.html (16.11.2017).

www.state.gov/t/isn/5191.html (16.11.2017).

www.state.gov/t/isn/5195/htm (16.11.2017).

www.state.gov/t/isn/5205.html (16.11.2017).

www.states.gov/t/isn/5182.html (16.11.2017).

www.stimson.org (16.11.2017).

www.un.org (16.11.2017).

www.un.org (16.11.2017).

DOI: $10.7862 /$ rz.2021.hss.07

The text was submitted to the editorial office: December 2020.

The text was accepted for publication: March 2021. 
